\title{
Characterization of Tomato Landraces Grown under Organic Conditions Based on Molecular Marker Analysis and Determination of Fruit Quality Parameters
}

\author{
Mavromatis A. G. ${ }^{1}$, Athanasouli V. ${ }^{1}$, Vellios E. ${ }^{2}$, Khah E. ${ }^{1}$, Georgiadou E. C. ${ }^{3}$, Pavli O. I. ${ }^{4}$ \& Arvanitoyannis I. S. ${ }^{5}$ \\ ${ }^{1}$ Lab of Genetics \& Plant Breeding, School of Agricultural Sciences, University of Thessaly, Fytokou st. - N. Ionia, \\ Hellas \\ ${ }^{2}$ Lab of Phytopathology, School of Agricultural Sciences, University of Thessaly, Fytokou st., N. Ionia, Hellas \\ ${ }^{3}$ Technological University of Cyprus, Lemessos \\ ${ }^{4}$ Agricultural University of Athens, Lab of Plant Breeding \& Agr. Experimentation, Hellas \\ ${ }^{5}$ Lab of Food Technology, School of Agricultural Sciences, University of Thessaly, Fytokou st., N. Ionia, Hellas \\ Correspondence: Mavromatis A.G., Lab of Genetics \& Plant Breeding, School of Agricultural Sciences, \\ University of Thessaly, Fytokou st. - N. Ionia, Hellas. E-mail: amavromat@uth.gr
}

Received: October 24, 2012 Accepted: December 6, 2012 Online Published: January 15, 2013

doi:10.5539/jas.v5n2p239 URL: http://dx.doi.org/10.5539/jas.v5n2p239

\begin{abstract}
The present study aimed to assess seven tomato genotypes (commercial cultivars and local landraces) with respect to yield potential, physicochemical and sensory properties when cultivated under organic conditions, over two growing seasons. Traits like yield ingredients and fruit quality were measured whereas, the morphological traits were assessed according to the UPOV classification, starting from the seedling stage until the stage of fruit maturity. Total yield per plant and cultivar determined, while assessment of fruit quality was performed on the basis of physicochemical characteristics (content in vitamin $\mathrm{C}$, acidity, $\mathrm{pH}$ of the juice, soluble materials). Genotype fingerprinting was performed by means of RAPD analysis. Following a preliminary evaluation of 50 RAPD primers, 10 polymorphic primers were selected and used in RAPD-PCRs. Statistical data analysis revealed significant differences in a range of characteristics under study whereas at the same time, yield was significantly different both among the varieties and the harvest stages. Interestingly, the landraces tested, especially Homiricon and Lotos, presented important organoleptic attributes under organic growing conditions and were met with high consumer acceptance, thus suggesting their possible direct exploitation in the market or after the application of an intravarietal selection breeding program.
\end{abstract}

Keywords: tomato landraces, organic breeding, organoleptic attributes, RAPD analysis, Leveillula taurica

\section{Introduction}

Tomato is one of the most extensively studied cultivated plant species grown all over the world, occupying globally a cultivation area of approximately 4.338 .834 million hectares (FAOSTAT, 2010). The positive role of tomato on human nutrition has been mainly attributed to its high content in vitamin $\mathrm{C}$ and carotenoids constituents, particularly lycopene and b-carotene, accumulated in plasma and tissues (Dorais et al., 2008; Aust et al., 2003; Gerster, 1997; Clinton et al., 1996). The agronomic value of tomato has been greatly enhanced by plant breeding, while many desirable traits have been introduced in cultivated tomato after crosses with wild relatives (Rick, 1978). The latter, are a valuable gene pool for important fruit quality traits including soluble solids, $\mathrm{pH}$ and lycopene (Chen et al., 1999). Landraces represent the earliest form of available cultivars and are generally conceived as intermediate stages of the domestication process. In contrast to modern-day cultivars, landraces are highly heterogeneous as they were systemically selected for their performance in adverse agricultural environments (Fernie et al., 2006). The description and evaluation of tomato varieties based on several physicochemical and sensory parameters which are referred taste, flavor (Georgelis et al., 2004), nutritional value (Di Mascio et al., 1989), color (Atherton \& Rudish, 1986), content of vitamin C, texture, hardness, pH and acidity (Madhavi \& Salunkhe, 1998) are regarded as the most important. In recent years, eexcept of morphological and sensory parameters, the molecular markers have been deployed for various genomic studies (Foolad \& Panthee, 2012; 
Collard \& Mackill, 2008) as well as map construction and detection of polymorphisms in plants (Staub et al., 1996; Stam et al., 1993; Williams et al., 1993; Carelli et al. 2006). Genetic analysis by RAPD molecular markers represents a popular method for the detection of genetic polymorphisms (Sarris et al., 2005). Such markers offer quick screening of different genomic regions for genetic polymorphisms (Echeverrigaray, 2006). In relation to other marker types, RAPDs display great advantages which refer to the following: no prior knowledge of the target sequence is needed for the design of primers, nanogram DNA quantities are used, results are directly interpreted and during PCR the whole genome is surveyed (Benter et al., 1995).

The present study aimed to describe and evaluate four tomato bred lines originated from local landraces after a three year pure line selection under organic growing conditions in relation to three commercial varieties, as a means to initially investigate the potential of their exploitation as parents in commercial hybrid production or their direct use as commercial varieties with superior quality performance. To this purpose, assessment was performed on the basis of morphological traits, according to UPOV, as well as important sensory and physicochemical characteristics. Moreover, resistance to powdery mildews (Leveillula taurica) affecting the organic tomatoes cultivated in Mediterranean zone, was estimated. Furthermore, RAPD molecular marker analysis was employed, for fingerprinting and characterizing the cultivated tomato genetic material.

\section{Materials and Methods}

\subsection{Plant Material \& Agronomical Practices}

The genetic material used in this study included four bred lines originated from traditional tomato cultivars: Homiricon, Panagitsa, Pelion and Lotos and three commercial varieties: Belladona, Ace and Macedonia. The bred lines were selected from the local cultivars after 3 cycles of pure line selection (Figure 1) (Mavromatis et al., 2008).

The final evaluation of the above mentioned material was applied for two years in the organic experimental field of the University of Thessaly followed the protocol of growing practices for organic farming (Council Regulation (E.E.C.) 2092/91). At the two growing seasons, systemic irrigation was applied using 430-450 $\mathrm{mm}$ of water per experimentation period, by means of the surface drip method. Tomato seeds from all cultivars were sown in Primo-Subsaat and, seedlings were transplanted one month later. The experimental design employed was Randomised Complete Block (RCBD), with three replications including all tomato cultivars, each represented by 15 plants. Harvesting was performed in the following 7 time periods: 74 days after transplantation (DAT), 84 DAT, 90 DAT, 100 DAT, 117 DAT, 130 DAT and finally in 137 DAT. Criterion of harvest was the fruit color while attribution and number of fruits per plant, genotype and harvest phase were recorded. For this purpose, GA200D balance was used with measurement accuracy of $1 / 10 \mathrm{~g}$.

\subsection{Description of Morphological Characteristics}

For the determination of local lines' identity, five tomato plants per accession were evaluated for 18 morphological characteristics, based on UPOV's squash descriptor list (UPOV, 2001). The morphological characteristics recorded, were: leaf size and color, number and type of inflorescence, flower color, position of abscission layer, fruit size length, ratio of length and fruit diameter, fruit structure, pericarp bulk cell size, number of germen places, presence or absence of "green shoulder", fruit and flesh color. Data were scored using a metric scale (1-9) according to the descriptor list of UPOV (upov.org).

\subsection{Evaluation for Resistance to Leveillula taurica (Lev.)}

Thirty tomato plants of each variety were used to estimate the disease severity. Natural infection of Leveillula taurica occurred and the first symptoms of the disease were obvious 90 DAT. Seven plants were selected randomly at 117 DAT and 10 middle leaves from each plant were used in order to estimate the percentage of the diseased leaf area. The leaflets with light green to bright yellow lesions were categorized into 4 groups according to disease assessment scale from 0 to 3 . The whole process was repeated at 130 DAT. The disease severity (DS) was estimated with the formula:

$$
D S=[(M 1 * V 1+M 2 * V 2+M 3 * V 3+M 4 * V 4) / N] * 100 \%
$$

$\mathrm{M} 1,2,3,4=$ average of lesions in each group of the disease assessment scale

$\mathrm{V} 1,2,3,4=$ number of leaflets grouped to each group of the disease assessment scale

$\mathrm{N}=$ total number of leaflets $(V 1+V 2+V 3+V 4)$ 


\subsection{Evaluation of Sensory and Physicochemical Properties}

For the purpose of assessing traits like appearance, flavor, smell, feel and general acceptance, a test panel, consisting of 10 persons, was employed for assessing specimens of the tomato genotypes under study. Testing was performed in the laboratory of Genetics and Plant Breeding (University of Thessaly) and was recorded in a graded form. The content of vitamin $\mathrm{C}$ was determined with an apparatus MERCK RQ fle2 with Ascorbic Acid Test $25-450 \mathrm{mg} / 1$. Ten (10) $\mathrm{g}$ of tomato juice were diluted in $10 \mathrm{~g}$ distilled water, while MERCK tape was dipped in the solution for $2 \mathrm{sec}$. After $10 \mathrm{sec}$, the MERCK tape was inserted in the apparatus for $5 \mathrm{sec}$ and subsequently, the indication of apparatus was set at $100 \mathrm{gr}$ specimen, to produce a characteristic curve. As regards $\mathrm{pH}$, measurements were carried out in $10 \mathrm{ml}$ dilution of tomato juice, at 19 DAT by a digital pHmeter, standardized with buffers in $\mathrm{pH} 4$ and 7. In a similar dilution, 2-3 drops of phenylphtalein $1 \% \mathrm{v} / \mathrm{v}$ (index) were added and titration with $\mathrm{NaOH}$ $0.1 \mathrm{~N}$ was conducted. The content of dilution in citric acid\% was calculated by multiplying the titrated volume of $\mathrm{NaOH}$ with 0.064 .

In terms of fruit hardness, penetration apparatus FT 011 Italy Bishop was used in 119 DAT. The apparatus was placed and pressed in fruit surface, with the aim to determine pressure in $\mathrm{Kgf} / \mathrm{cm}^{2}$. Ten (10) $\mathrm{g}$ of pressed tomato were used as filtrate to determine the soluble solids constituents with a diffractometer with the accuracy of 0.2 .

\subsection{Molecular Analysis through DNA Extraction and RAPD-PCRs}

Genomic DNA was isolated from young, healthy leaves in a total weight of $0.3 \mathrm{gr}$, with a modified CTAB method (Doyle \& Doyle, 1990). DNA concentration was determined with spectrophotometer at $260 \mathrm{~nm}$ absorption, while qualitative assessment was performed by the A260/280 ratio. Moreover, DNA samples were qualitatively and quantitatively evaluated by means of agarose gel electrophoresis in (1\%) gels, stained with ethidium bromide and examined under ultraviolet light. Following a preliminary evaluation of 50 RAPD primers (Operon Co. Ltd., USA) (Mavromatis et al., 2008), 10 polymorphic primers were selected and used in PCR reactions. PCR reaction mixture contained $20 \mathrm{ng}$ genomic DNA as template, 1x PCR buffer, $1.6 \mathrm{mM}$ 10-mer primer (Operon Tech.), $2.5 \mathrm{mM}$ $\mathrm{MgCl}_{2}, 200 \mu \mathrm{M}$ dNTPs, 2 u Taq DNA polymerase (Minotech), and $\mathrm{mQ} \mathrm{H}_{2} \mathrm{O}$ in a final volume of $25 \mu \mathrm{l}$. The employed temperature profile consisted of an initial denaturation for $6 \mathrm{~min}$ at $94^{\circ} \mathrm{C}$, then 40 cycles composed of 1 sec at $94^{\circ} \mathrm{C}, 1 \mathrm{sec}$ at $36^{\circ} \mathrm{C}, 1.3 \mathrm{~min}$ at $72^{\circ} \mathrm{C}$ with a final extension cycle at $72^{\circ} \mathrm{C}$ for $7 \mathrm{~min}$. Amplification products were visualized similarly to the procedure described by Mavromatis et al. (2010).

\subsection{Data/Statistical Analysis}

In an attempt to determine the genetic diversity, gel scoring was performed on the basis of binary format where the presence and absence of a band was scored as 1 and 0 , respectively. Genetic similarity was calculated using the Jaccard $\mathrm{S}_{\mathrm{ij}}=\mathrm{a} /(\mathrm{a}+\mathrm{b}+\mathrm{c})$ (Sneath \& Sokal, 1973) and Dice coefficients Dice $\mathrm{S}_{\mathrm{ij}}=2 \mathrm{a} /(2 \mathrm{a}+\mathrm{b}+\mathrm{c})($ Nei \& Li, 1979), where $\mathrm{S}_{\mathrm{ij}}$ is genetic analogy of specimens, a corresponds to the number of polymorphic DNA section in specimens $\mathrm{i}$ and $\mathrm{j}$, $\mathrm{b}$, the number of polymorphic DNA section in specimen $\mathrm{i}$ and $\mathrm{c}$, the number of polymorphic DNA section in specimen $\mathrm{j}$. Clustering was based on the unweighted pair group method with arithmetic mean (UPGMA) and neighbor joining (NJ) methods. All data analyses were carried out using the NTSYS software version 2.11e (Rohlf, 2002). Statistical analysis for morphological, physicochemical and sensory characteristics was accomplished with SPSS 12.0 software. A two-factor ANOVA analysis was also performed. As regards the physicochemical and sensory characteristics, cluster analysis and principal component analysis (PCA) were conducted by using the software (JMP 5.0.1).

\section{Results}

\subsection{Yield Performance}

Yield was estimated on the basis of the following parameters: yield per harvest stage and cultivar, total yield per cultivar and fruit weight per plant (Table 1). In addition, the following yield components were determined: number of fruits per harvest stage, total number of fruits for each cultivar and fruit number per plant and were calculated at 7 harvest stages (Figure 2a \& b). Regarding fruit weight, statistical analysis revealed significant differences among the totato genotypes, especially in $1^{\text {st }}\left(74\right.$ DAT), $3^{\text {rd }}\left(90\right.$ DAT) and $5^{\text {th }}(117$ DAT) harvest stages while in other harvests, significant differences in total yield and in fruit weight per plant were not found. More specifically, at $1^{\text {st }}$ harvest stage (74 DAT), the commercial variety Macedonia presented the highest yield $(2.54 \mathrm{~kg})$, characterized as the earliest in comparison to all other tomato varieties tested. In relation to earliness, Macedonia was followed by Lotos $(1.78 \mathrm{~kg})$, Panagitsa $(1.44 \mathrm{~kg})$, Belladona $(1.20 \mathrm{~kg})$, Homiricon $(0.81 \mathrm{~kg})$, Ace $(0.78 \mathrm{~kg})$ and finally, Pelion $(0.39 \mathrm{~kg})$. At the $3^{\text {rd }}$ harvest (90 DAT), the landrace Homiricon had the highest yield, while Lotos had the lowest. As shown in Figure 1a \& b, the most productive period for tomato production was from 100 DAT to 130 DAT. During this period, the landrace Homiricon, gave the highest yield with respect to fruit weight $(27.94 \mathrm{~kg})$ per 10 
plants, while the lowest yield was recorded in the landrace Panagitsa $(15.77 \mathrm{~kg})$. Significant differences in total yield and fruit number per plant among the 7 cultivars tested, were recorded only during the $1^{\text {st }}$ and $5^{\text {th }}$ harvest stage. Regarding total fruit production, the bred line of Lotos scored the highest number of well ripened fruits (163) and was followed by Macedonia (155.67), while Homiricon presented on average the lowest value of fruits (82.33) unless this trait is negatively related with the size of fruits (Table 1).

Table 1. Assessment of yield components (total fruit number, fruit number per plant, total yield per cultivar and fruit weight per plant) for the tomato cultivars tested

\begin{tabular}{lcccc}
\hline Cultivars & Total fruit number & Fruit number per plant & Total yield & Fruit weight per plant \\
\hline Lotos & $163,00 \mathrm{c}$ & $14,27 \mathrm{c}$ & $20.31 \mathrm{ab}$ & $1.89 \mathrm{ab}$ \\
Macedonia & $155,67 \mathrm{bc}$ & $14,30 \mathrm{c}$ & $21.55 \mathrm{ab}$ & $2.01 \mathrm{ab}$ \\
Panagitsa & $105,00 \mathrm{ab}$ & $9,77 \mathrm{ab}$ & $15.77 \mathrm{a}$ & $1.64 \mathrm{a}$ \\
Belladona & $138,67 \mathrm{abc}$ & $12,52 \mathrm{bc}$ & $17.84 \mathrm{a}$ & $1.67 \mathrm{a}$ \\
Pelion & $124,00 \mathrm{abc}$ & $14,42 \mathrm{c}$ & $16.22 \mathrm{a}$ & $1.98 \mathrm{ab}$ \\
Ace & $87,33 \mathrm{a}$ & $8,12 \mathrm{a}$ & $16.86 \mathrm{a}$ & $1.54 \mathrm{a}$ \\
Homirikon & $82,33 \mathrm{a}$ & $7,42 \mathrm{a}$ & $27.94 \mathrm{~b}$ & $2.51 \mathrm{~b}$ \\
\hline Average & 122,29 & 11,55 & 19.50 & 1.89 \\
Sx & 2,43 & 1,10 & 2.89 & 0.24 \\
LSD 0,5 & 51,42 & 3,40 & 8.77 & 0.74 \\
CV\% & 704,95 & 31,60 & 128.51 & 9.25 \\
S.S & $*$ & $* * *$ & $n s$ & ns \\
\hline
\end{tabular}

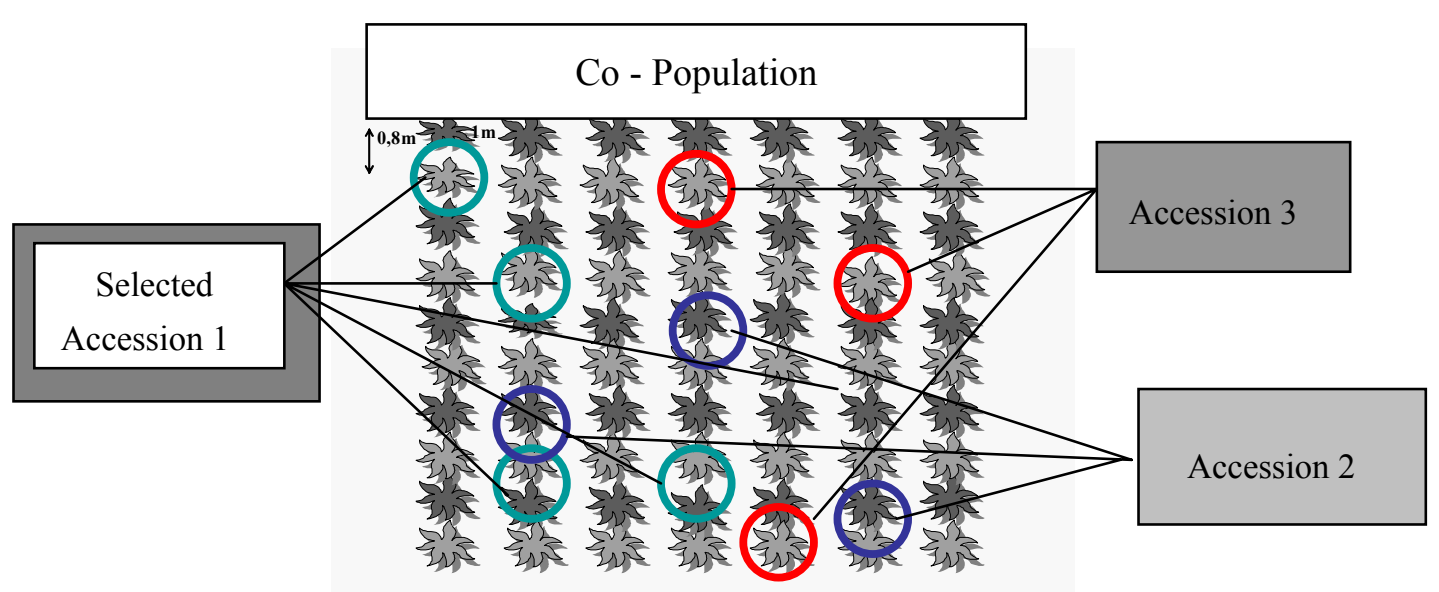

Figure 1. Breeding scheme of "pure line selection" applied for 3 years in 4 traditional tomato cultivars (Lotos, Homirikon, Panagitsa, Pelion) 

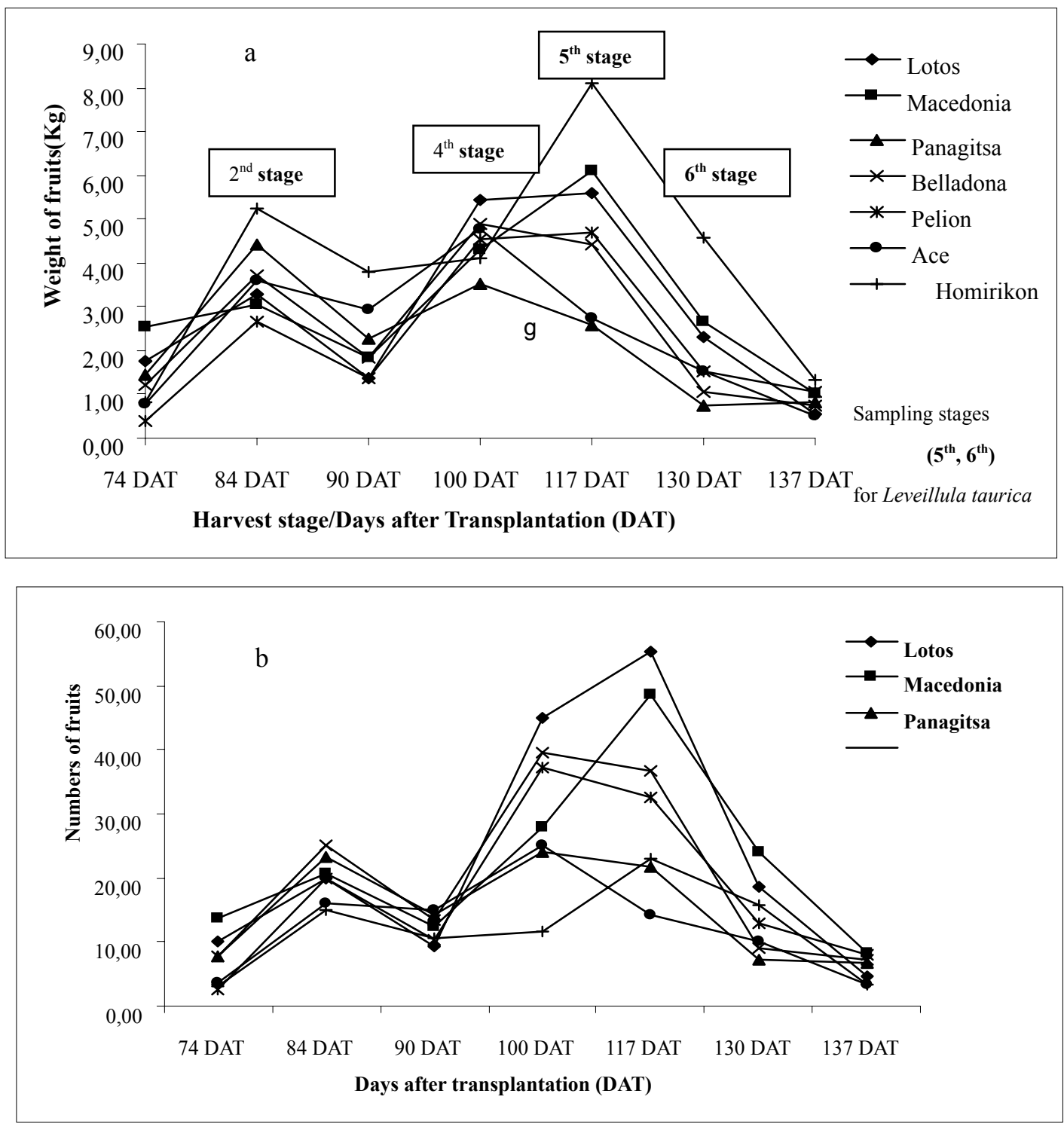

Figure 2. (a) Fruit weight per cultivar and harvest stage (DAT) \& (b) Fruit number per cultivar at different harvest stages for the tomato seven cultivars tested

\subsection{Morphological Characteristics by UPOV}

Morphological evaluation of the genotypes tested referred to the following parameters: leaf length, size and intensity of green color, number and type of inflorescences, flower color, abscission layer, fruit size length, ratio of length and fruit diameter, fruit configuration, pericarp bulk, cell size, number of germen places, presence or absence of "green shoulder", fruit and flesh color (Table 2). 
Table 2. Assessment of morphological characteristics for seven tomato cultivars, tested. Numbers referred to the corresponding characteristics as described in UPOV catalogue (upov.org)

\begin{tabular}{|c|c|c|c|c|c|c|c|c|c|c|c|c|}
\hline \multirow{2}{*}{$\begin{array}{l}\text { Characteristics } \\
7 \text { Leaf: length }\end{array}$} & \multicolumn{12}{|c|}{ LotosMacedoniaPanagitsaBelladonaPelion Ace HomirikonMEAN Sx LSD 0,5CV\% Fx } \\
\hline & 31.69 & 33.38 & 33.46 & 30.83 & 33.4 & 31.89 & 33.93 & 32.65 & 0.82 & 2.34 & 0.00 & ns \\
\hline 10 Leaf: size of leaflets in middle of leaf & 25.5 & 26.44 & 25.24 & 27.81 & 27.63 & 27.25 & 26.53 & 26.63 & 1.06 & 3.04 & 0.00 & ns \\
\hline 11 Leaf: intensity of green color & 3 & 7 & 5 & 5 & 5 & 7 & 3 & - & - & - & - & - \\
\hline 3 Plant: number of inflorescences on main stem & 5 & 5 & 5 & 5 & 5 & 5 & 5 & - & - & - & - & - \\
\hline 16 Inflorescence: type $2^{\text {nd }}$ and $3^{\text {rd }}$ truss & 2 & 2 & 2 & 1 & 2 & 1 & 2 & - & - & - & - & - \\
\hline 19 Flower: color & 1 & 1 & 1 & 1 & 1 & 1 & 1 & - & - & - & - & - \\
\hline 20 Peduncle: abscission layer & 9 & 9 & 9 & 9 & 9 & 9 & 9 & - & - & - & - & - \\
\hline 22 Fruit size & 7 & 7 & 5 & 5 & 7 & 7 & 9 & - & - & - & - & - \\
\hline Fruit: length & $6,38 \mathrm{a}$ & $6,52 \mathrm{a}$ & $6,48 \mathrm{a}$ & $6,8 \mathrm{ab}$ & $6,52 \mathrm{a}$ & $7,3 b$ & $9,9 \mathrm{c}$ & 7,13 & 0,23 & 0,67 & $3,86 *$ & $* * *$ \\
\hline Fruit: diameter & $8,56 \mathrm{~b}$ & $8,36 \mathrm{a}$ & $7,88 \mathrm{a}$ & $7,54 \mathrm{a}$ & $8,04 \mathrm{a}$ & $8,9 \mathrm{c}$ & $10,54 d$ & 8,55 & 0,31 & 0,88 & $5,56 *$ & $* * *$ \\
\hline 31 Fruit: size of core in cross section & $2,18 \mathrm{a}$ & $3,62 b$ & $2,28 \mathrm{a}$ & $2,36 \mathrm{a}$ & $2,66 \mathrm{a}$ & $2,44 \mathrm{a}$ & $5,62 \mathrm{c}$ & 3,02 & 0,3 & 0,85 & $14,62 *$ & $* * *$ \\
\hline 32 Fruit: thickness of pericarp & $0,42 \mathrm{a}$ & $0,52 b$ & $0,42 \mathrm{a}$ & $0,54 b$ & $0,48 \mathrm{a}$ & $0,46 \mathrm{a}$ & $0,48 \mathrm{a}$ & 0,47 & 0,03 & 0,08 & 0,84 & $*$ \\
\hline 33 Fruit: number of locules & $0,42 \mathrm{a}$ & $0,52 b$ & $0,42 \mathrm{a}$ & $0,54 b$ & $0,48 \mathrm{a}$ & $0,46 \mathrm{a}$ & $0,48 \mathrm{a}$ & 0,47 & 0,03 & 0,08 & 0,84 & $*$ \\
\hline 24 Fruit: shape in longitudinal section & 2 & 2 & 3 & 4 & 3 & 3 & 7 & - & - & - & - & - \\
\hline 34 Fruit: green shoulder & 9 & 1 & 1 & 1 & 9 & 9 & 9 & - & - & - & - & - \\
\hline 35 Fruit: extent of green shoulder & 5 & - & - & - & 3 & 7 & 5 & - & - & - & - & - \\
\hline 38 Fruit: color at maturity & 3 & 5 & 5 & 4 & 3 & 4 & 3 & - & - & - & - & - \\
\hline 39 Fruit: color of flesh at maturity & 5 & 5 & 4 & 5 & 4 & 5 & 4 & - & - & - & - & - \\
\hline
\end{tabular}

Data analysis revealed statistical significant differences among varieties mainly in fruit length and diameter and also in size of core in cross section with are countable characteristics. In terms of fruit length, the cultivars Lotos, Panagitsa, Pelion and Macedonia had approximately the same length. The landrace Homiricon was characterized by large size of fruits according to length, diameter and fruit core.

\subsection{Cluster Analysis for Morphological Characteristics}

Cluster analysis for morphological characteristics allowed the construction of two dendrograms: one for the classification of morphological characteristics per se (Figure 3a) and one for the classification of varieties with respect to such traits (Figure $3 b$ ). 


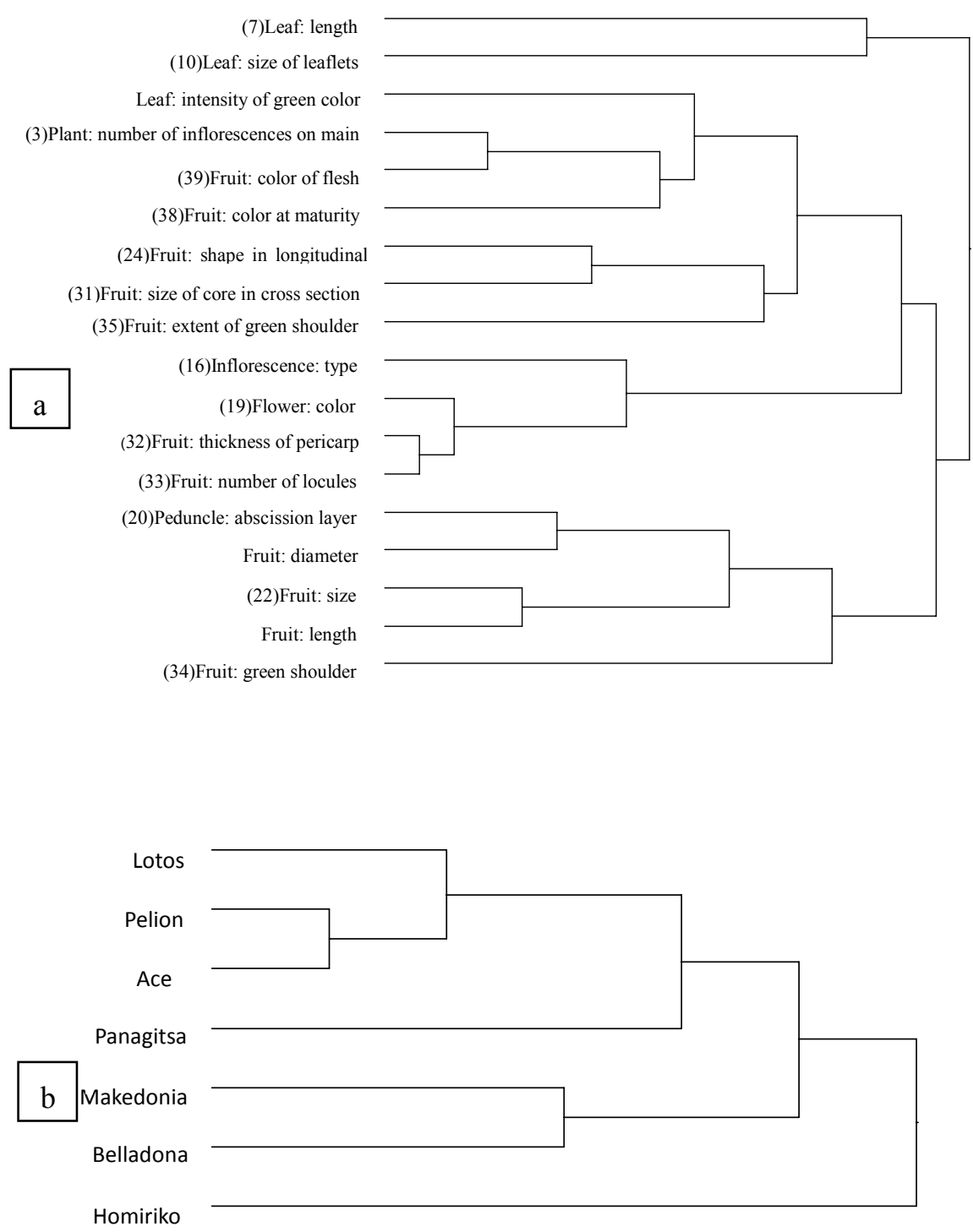

Figure 3. (a) Cluster analysis of morphological traits for 7 tomato cultivars according to UPOV descriptor list. (b) Cluster analysis for genetic relationships of 7 tomato cultivars, according to morphological characteristics (UPOV)

In Figure 3a, presented the classification of morphological charachteristics into 3 suite groups: i) characteristics of leaf i.e. length and size; ii) characteristics of fruits (color of flesh, color of maturity, shape in longitudinal section, size of core in cross section, extent of "green shoulder", thickness of pericarp, number of locules) were grouped together with characteristics of leaf (intensity of green color), characteristics of plant (number of inflorescences, on main stem), characteristics of inflorencence (type), and characteristics of flower (color); iii) characteristics of fruits (diameter, size, length, "green shoulder") grouped together with peducle (abscission layer).

Furthermore, in Figure $3 \mathrm{~b}$ showed the classification of varieties with respect to their morphological characteristics. Tomato cultivars are clasiffied in 3 suite groups: i) Lotos, Pelion, Ace; ii) Panagitsa, Macedonia and Belladona and i) Homirikon which is well differentiated from the other tomato cultivars. 


\subsection{Resistance to Leveillula taurica (Lev.)}

At the first sampling stage (117 DAT), the landrace Homirikon was shown to be less susceptible from the rest of tomato cultivars with $\mathrm{DS}=1.943 \%$ and Macedonia the most susceptible (DS=19,771\%). A group of 3 varieties didn't differ statistically (Panagitsa DS $=6.229 \%$, Ace DS $=7.329 \%$, Lotos DS=8.871\%) followed by another group includes (Belladona DS=9.857\% and Pelion DS=11.800\%). At the second sampling stage (130 DAT), the less susceptible varieties were Homirikon ( $\mathrm{DS}=9.286 \%$ ) and Ace $(\mathrm{DS}=8.871 \%$ ). Belladona and Pelion showed similar percentage of disease severity $(\mathrm{DS}=22.786 \% \& \mathrm{DS}=16.32187 \%)$ respectively, followed by Panagitsa $(\mathrm{DS}=$ $28.529 \%$ ). Finally the most susceptible varieties were Lotos and Macedonia with DS $=37.314 \%$ and DS $=37.343 \%$, respectively.

\subsection{Fruit Quality Parameters}

Assessment of fruit quality pertained to the following parameters: $\mathrm{pH}$, acidity (\% citric acid) and content in ascorbic acid (vitamin C), soluble solids (\%) and flesh resistance in pressure. All above characteristics were evaluated at 119 days after transplantation (DAT) (Table 3). Calibrations of $\mathrm{pH}$ presented normal values for all varieties in a range between 4.0 and 5.0. Landraces Homiricon and Panagitsa presented higher $\mathrm{pH}$ values, while the values of Macedonia and Lotos were close to the desirable levels. Fruit content in vitamin $\mathrm{C}$ varied considerably and was generally lower in most of genotypes tested in comparison with the average vitamin content, which is 25 $\mathrm{mg}$ vitamin $\mathrm{C} / 100 \mathrm{~g}$ in tomato. Landrace Homiricon was characterized by the lowest vitamin C content $(9.37 \mathrm{mg}$ vitamin $\mathrm{C} / 100 \mathrm{~g}$ tomato) while Lotos and the commercial cultivar "Macedonia" had the highest values (26.30 $\mathrm{mg}$ and $22.85 \mathrm{mg}$ of vitamin $\mathrm{C} / 100 \mathrm{~g}$ tomato). The lowest percentage in soluble solids was found in Panagitsa, while all other varieties ranged at similar satisfactory levels. Hardness was highly variable among the cultivars tested, as it is affected by production/cultural conditions. The landrace Homiricon had the highest hardness degree, while Ace and Panagitsa presented the lowest level (Table 3). The most dominant acid in tomato is citric, whose presence is assigned fruit's characteristic acidity. Citric acid was estimated by volume $(\mathrm{ml})$ of $\mathrm{NaOH} 0,1 \mathrm{~N}$ consumption during volumetric analysis. Table 3 summarizes the quantity $(\mathrm{ml})$ of $\mathrm{NaOH} 0,1 \mathrm{~N}$ consumption during volumetric analysis for each variety and citric acid content. Citric acid content ranged at similar levels for the cultivars studied. However, the highest acidity ratio (3.65\%) was found in the commercial variety Belladona, and the lowest $(2.82 \%)$ in the landrace Pelion.

Table 3. Assessment of fruit quality characteristics for tomato cultivars tested.

\begin{tabular}{lccccc}
\hline Cultivars & $\mathrm{pH}$ & $\begin{array}{c}\text { Vitamin C } \\
(\mathrm{mg} / \text { 100 g tomato })\end{array}$ & Soluble solids (\%) & Flesh Hardness & Acidity (\%) \\
\hline Lotos & 3.99 & 26.30 & 5 & 2.61 & 3.33 \\
Macedonia & 3.98 & 22.85 & 5.2 & 2.16 & 3.26 \\
Panagitsa & 4.21 & 11.67 & 3.4 & 1.96 & 3.26 \\
Belladona & 4.02 & 15.29 & 5.2 & 2.67 & 3.65 \\
Pelion & 4.05 & 15.12 & 5.3 & 2.18 & 2.82 \\
Ace & 4.11 & 13.32 & 4.9 & 1.96 & 3.14 \\
Homirikon & 4.22 & 9.37 & 5.1 & 3.34 & 2.88 \\
\hline
\end{tabular}

\subsection{Sensory Characteristics}

The analysis of sensory characteristics of the genotypes tested referred to the following parameters: exterior elements (color, brightness), feel, smell, gristliness and total impression. Such data are presented in Table 4. Data analysis revealed statistically significant differences among varieties in all sensory parameters. 
Table 4. Assessment of sensory characteristics for the tomato cultivars tested.

\begin{tabular}{|c|c|c|c|c|c|c|c|c|c|c|c|c|c|c|c|c|c|}
\hline \multirow{2}{*}{ Cultivars } & \multicolumn{2}{|c|}{ Exterior appearance } & \multicolumn{12}{|l|}{ Taste } & \multirow{2}{*}{ Smell } & \multirow{2}{*}{$\begin{array}{l}\text { Feel } \\
\text { Gristly }\end{array}$} & \multirow{2}{*}{ Total impression } \\
\hline & Color & Brightness & Salinity & Bitterness & Acridity & Sweetness & Herbaceous & Mineral & Mouldy & Acid & Retain Taste & Consistency & Tooth Adhesion & Fleshy & & & \\
\hline Lotos & $3,3 \mathrm{bc}$ & $2,7 \mathrm{a}$ & $3,9 \mathrm{a}$ & $4,2 \mathrm{bc}$ & $3,9 \mathrm{a}$ & 2,9abc & $3,4 b c$ & $3,5 a$ & $4,4 \mathrm{bc}$ & $3,1 \mathrm{a}$ & 2,7abc & $3,8 \mathrm{c}$ & $4,5 \mathrm{~b}$ & $3,7 \mathrm{ab}$ & $2,9 \mathrm{a}$ & 3,4abc & $3,6 \mathrm{c}$ \\
\hline Macedonia & $3,7 \mathrm{~cd}$ & $3,5 \mathbf{b}$ & $4,4 a$ & 3,9ab & $3,8 \mathrm{a}$ & $2,5 \mathrm{ab}$ & 3, labc & 3a & 3,6ab & $3,6 \mathrm{ab}$ & $3 \mathrm{bc}$ & $2,9 \mathrm{bc}$ & $3,7 \mathrm{ab}$ & 3a & 3,2ab & $3 a b$ & $3 \mathrm{~b}$ \\
\hline Panagitsa & 2,9ab & $2,6 \mathrm{a}$ & $4,1 \mathrm{a}$ & 3.8ab & 4,1ab & $3,1 \mathrm{bc}$ & 3,1abc & $3,5 \mathrm{a}$ & 3,6ab & $3,7 \mathrm{ab}$ & $3,1 \mathrm{bc}$ & $3,2 \mathrm{bc}$ & $4,1 \mathrm{~b}$ & $3,3 \mathrm{a}$ & 3,4ab & $3,6 \mathrm{bc}$ & $3,1 \mathrm{bc}$ \\
\hline Belladona & $2,6 \mathrm{a}$ & 3, lab & $4,1 \mathrm{a}$ & $4,1 \mathrm{bc}$ & $3,4 a$ & $2,2 \mathrm{ab}$ & 2,5ab & $3,5 a$ & $4,5 \mathrm{bc}$ & $2,7 \mathrm{a}$ & 2,7abc & $2 a$ & $3 a$ & $2,8 \mathrm{a}$ & $2,9 \mathrm{a}$ & $3 a b$ & $2,9 \mathrm{~b}$ \\
\hline Pelion & $2,6 \mathrm{a}$ & $2,7 \mathrm{a}$ & $4 a$ & $3 \mathrm{a}$ & $3,2 \mathrm{a}$ & $1,9 \mathrm{ab}$ & $2,3 \mathrm{a}$ & $3,1 \mathrm{a}$ & $2,9 \mathrm{a}$ & $2,8 \mathrm{a}$ & $2 a$ & $3,2 \mathrm{bc}$ & $3,7 \mathrm{ab}$ & $3,6 \mathrm{ab}$ & $2,6 \mathrm{a}$ & $2,8 \mathrm{a}$ & $1,6 \mathrm{a}$ \\
\hline Ace & $4,2 \mathrm{~d}$ & $3,4 \mathbf{b}$ & $4 a$ & 3,4ab & $4 a$ & $1,8 a$ & $3,7 \mathrm{c}$ & $3,4 a$ & $4,7 \mathrm{bc}$ & $2,7 \mathrm{a}$ & $3,6 \mathrm{c}$ & $3,1 b c$ & $4,1 \mathrm{~b}$ & $4,2 b$ & $3 \mathbf{a}$ & 3,3abc & $2,8 \mathbf{b}$ \\
\hline Homirikon & $2,5 \mathrm{a}$ & $3,4 \mathrm{~b}$ & $4 a$ & $5 \mathrm{c}$ & $4,9 \mathrm{~b}$ & $3.7 \mathrm{e}$ & $3,9 \mathrm{c}$ & $4,7 \mathrm{~b}$ & $5 c$ & $4,3 \mathrm{~b}$ & 2,2ab & 2,5ab & $4,3 \mathrm{~b}$ & 3,6ab & $3,9 \mathrm{~b}$ & $3,8 \mathrm{c}$ & $5 \mathrm{~d}$ \\
\hline Average & 3,11 & 3,06 & 4,07 & 3,91 & 3,90 & 2,59 & 3,14 & 3,53 & 4,10 & 3,27 & 2,76 & 2,96 & 3,91 & 3.46 & 3,13 & 3,27 & 3,14 \\
\hline Sx & 0,23 & 0,22 & 0,28 & 0,35 & 0,29 & 0,38 & 0,30 & 0,31 & 0,36 & 0,36 & 0,29 & 0,29 & 0,26 & 0,28 & 0,28 & 0,25 & 0,19 \\
\hline $\operatorname{LSD} 0,5$ & 0,64 & 0,62 & 0,79 & 0,98 & 0,81 & 1,08 & 0,86 & 0,88 & 1,02 & 1,03 & 0,82 & 0,82 & 0,73 & 0,80 & 0,79 & 0,7 & 0,53 \\
\hline CV\% & 16,31 & 16 & 19,13 & 30,58 & 21,28 & 56,77 & 29,18 & 27,40 & 32,02 & 40,41 & 30,58 & 28,51 & 17,27 & 23,05 & 24,9 & 18,49 & 11,2 \\
\hline $\mathrm{Fx}$ & $* * *$ & $* *$ & ns & $* *$ & $* *$ & ${ }^{* * *}$ & $* *$ & $* *$ & $* * *$ & $*$ & $* *$ & ** & ${ }^{* * *}$ & $*$ & * & ns & $* * * *$ \\
\hline
\end{tabular}

In terms of exterior appearance and particular color, Ace seems to have the most intense color. Values varied from 4.2 for Ace, to 2.5 for Homiricon. In relation to brightness, Macedonia (3.5), Ace (3.4) and Homiricon (3.4) were evaluated as more bright than Panagitsa (2.6), Lotos (2.7) and Pelion (2.7). Regarding feel and smell, Homiricon was characterized by the most intense smell and feel, while statistical significant differences were not found in all other cases. Data concerning taste constituents, which were derived from sensory tests, are also presented in Table 4. Regarding salinity, no statistical significant differences were found among varieties analyzed. In terms of fruit sweetness, Homiricon scored the highest value (3.7), while Ace had the lowest. With respect to negative taste parameters, as bitter, acridity, herbaceous flavour, mineral taste, mouldiness, acidity and retain taste, Pelion seems to characterized by the lowest values (scale 5: no intense - 1: very intense) thus, rendering this landrace undesirable for consumption. To the contrary, Homiricon scored the highest values in abovementioned parameters. In relation to consistency, Lotos presented the highest value (scale 5: no intense - 1: very intense), fact that makes it less tenacious, while Belladona seems to be the most tenacious. In terms of tooth adhesion, Homiricon (4.3), Lotos (4.5) and Panagitsa (4.1), which are landraces, as well as the commercial variety Ace (4.1) presented low values. Finally, Ace was intensely fleshy while the lowest intensity appeared in Belladona.

In order to estimate the disease severity, 30In terms of fruit total impression, the panel members' opinion ranged from high (5) to low (1) scale impression (Table 4). The best impressions were obtained for Homiricon and Lotos. Mild acceptance was attributed to Macedonia, Belladona, Ace and Panagitsa, whereas, the least acceptance characterized Pelion. Finally, certain traditional cultivars like Homiricon and Lotos were characterized by satisfactory overall performance and were superior than commercial cultivated tomato varieties, as Belladona.

\subsection{Cluster Analysis for Fruit Quality Parameters}

Cluster analysis for sensory characteristics allowed the construction of two dendrograms: one for the classification of sensory characteristics per se (Figure 4a) and one for the classification of varieties with respect to such traits (Figure $4 b$ ). 


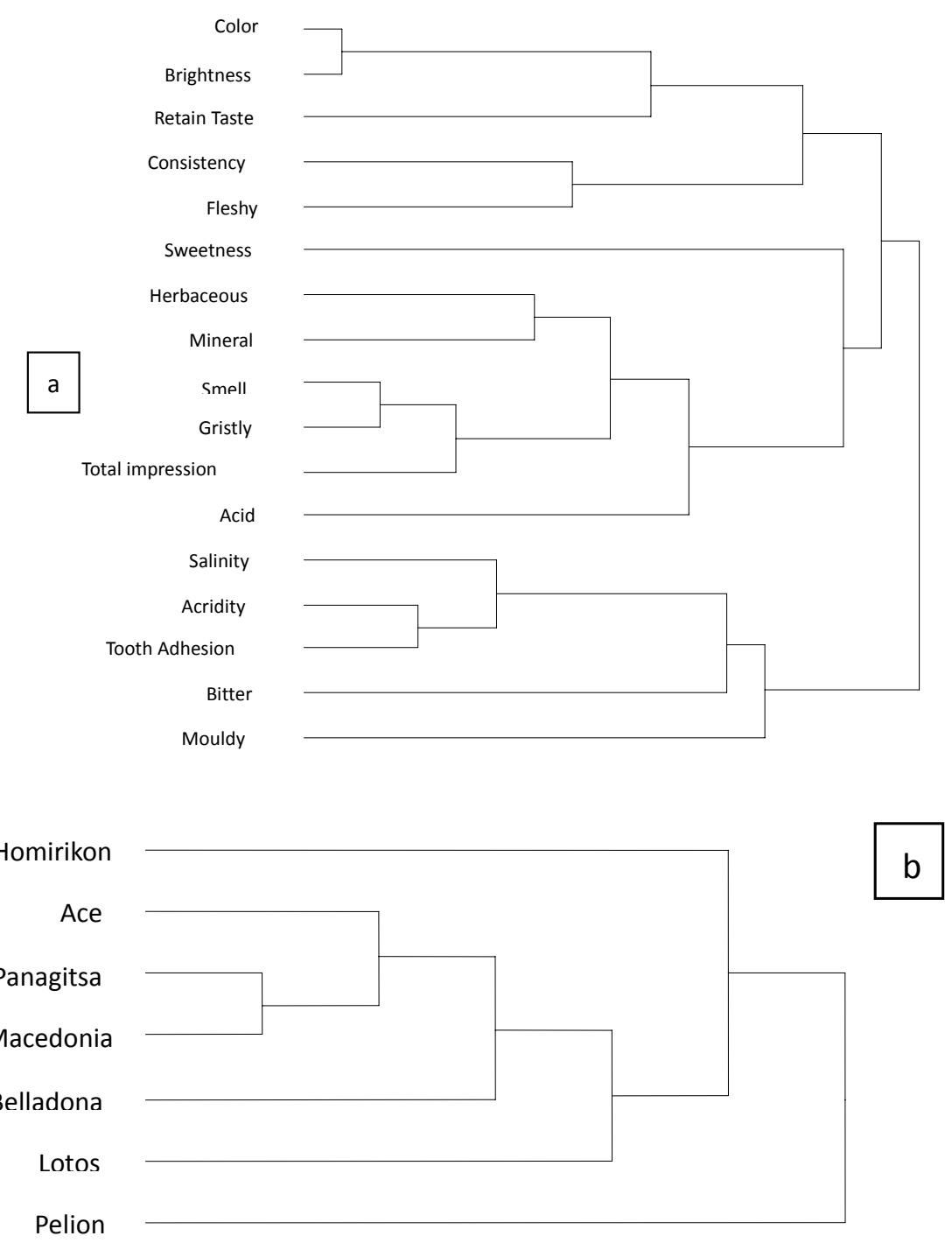

Figure 4. (a) Cluster analysis for sensory characteristics of seven tomato cultivars (b) Cluster analysis for genetic relationships of the seven tomato cultivars, according to sensory characteristics

Figure 4a configures the classification of sensory charachteristics into 3 suite groups: i) characteristics of exterior appearance (brightness and colour) grouped together with taste characteristics (retain taste, consistency and fleshiness), ii) characteristics of total appraisal (smell, feel) grouped together with taste characteristics (acidity, sweetness, herbaceous flavour and minelar taste), iii) characteristics related to the expression of taste (salinity, bitterness, teeth adhension, mouldiness and acerbate taste).

In figure $4 \mathrm{~b}$ showed the classification of tomato cultivars with respect to their sensory characteristics. According to this analysis, tomato cultivars are clasiffied in 3 suite groups: i) Ace, Panagitsa, Macedonia, Belladona, Lotos ii) Pelion and iii) Homirikon which were classified separetly from the others.

\subsection{Molecular Analysis of Tomato Cultivars Using RAPD Markers}

Following a preliminary evaluation of 50 RAPD primers, 10 primers were selected and used in RAPD-PCR reactions (Table 5). One of these primers proved to be monomorphic for all genotypes studied and therefore, was not included in further analyses. 
Table 5. Deduced RAPD profiles using 10 RAPD primers

\begin{tabular}{ccccc}
\hline $\begin{array}{c}\text { RAPD } \\
\text { primer }\end{array}$ & Sequence & $\begin{array}{c}\text { Number of } \\
\text { polymorphic } \\
\text { bands }\end{array}$ & $\begin{array}{c}\text { Total } \\
\text { amplification } \\
\text { products }\end{array}$ & $\begin{array}{c}\text { Polymorphic } \\
\text { information } \\
\text { content (PIC) }\end{array}$ \\
\hline OPC3 & 5'-GGGGGTCTTT-3' & 3 & 7 & $42,86 \%$ \\
OPC4 & 5'-CCGCATCTAC-3' & 1 & 6 & $16,66 \%$ \\
OPC5 & 5'-GATGACCGCC-3' & 2 & 5 & $40 \%$ \\
OPC6 & 5'-GAACGGACTC-3' & 2 & 4 & $50 \%$ \\
OPC8 & 5'-TGGACCGGTG-3' & 3 & 4 & $75 \%$ \\
OPC9 & 5'-TGGACCGGTG-3' & 2 & 5 & $40 \%$ \\
OPC10 & 5'-TGTCTGGGTG-3' & 1 & 4 & $25 \%$ \\
OPC11 & 5'-GTAGACCCGT-3' & 2 & 3 & $66,66 \%$ \\
OPC16 & 5'-CACACTCCAG-3' & 1 & 2 & $50 \%$ \\
OPC19 & 5'-GTTGCCAGCC-3' & 0 (Monomorphic) & 5 & $0 \%$ \\
\hline Total & & $\mathbf{1 7}$ & $\mathbf{4 5}$ & $\mathbf{3 7 , 7 7 \%}$ \\
\hline
\end{tabular}

The selected RAPD primers resulted in a total amplification of 45 bands, equally covering the genomic fragments amplified. The percentage of polymorphism was estimated at $37.77 \%$, as 17 out of the 45 genomic fragments amplified were polymorphic. The genotypic profiles produced by RAPD markers were scored manually. For the estimation of genetic diversity, gel scoring was performed on the basis of binary format where the presence and absence of a band was scored as 1 and 0 respectively. Representative banding patterns observed with primers OPC4 and OPC5 are shown in Figure 5.
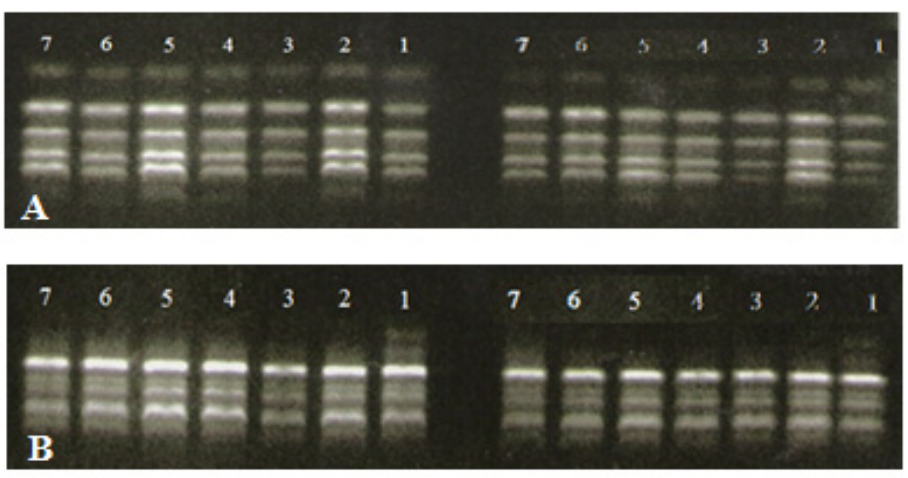

Figure 5. RAPD profile of seven tomato cultivars using the primer (A) OPC 4, (B) OPC 5. The numbers correspond to the 7 tomato genotypes studied as follows: 1: Belladona, 2: Homirikon, 3: Pelion, 4: Macedonia, 5: Ace, 6: Lotos, 7: Panagitsa

Genetic similarity was calculated using the Jaccard and Dice coefficients, whereas clustering was based on the unweighted pair group method with arithmetic mean (UPGMA) and neighbour joining (NJ) methods. Genetic similarity based on JACCARD/UPGMA algorithms, resulted on higher similarity coefficient ( $\mathrm{r}-0.82)$ in comparison with $\mathrm{NJ}(\mathrm{r}-0.55)$. Analysis revealed an extent of genetic heterogeneity among the tomato cultivars 
studied. However, genetic similarity was relatively high and ranged from 0.78 to 0.93 (Figure 6). Clustering according to UPGMA revealed that the cultivar Pelion is genetically distant to the other tomato cultivars. In addition, the commercial variety Belladona presented genetic divergence to the other cultivars. This is an expected result, because is originated from Italy. In contrast, samples originating from the cultivars Homirikon and Ace were genetically close and were grouped in the same cluster with Macedonia. The latter group was found related to the landraces Lotos and Panagitsa (Figure 6).

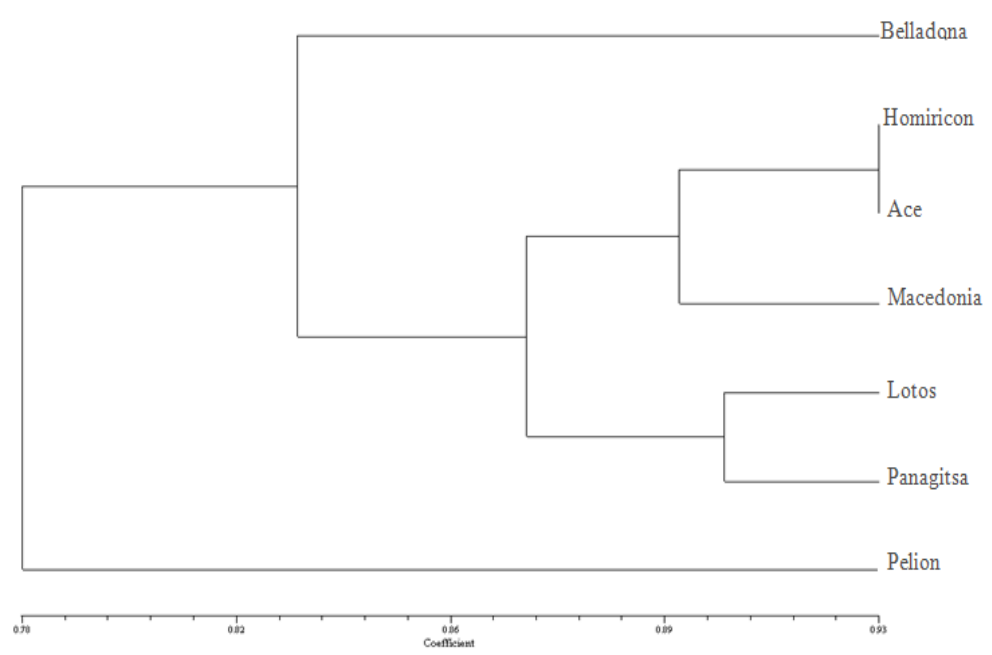

Figure 6. Genetic similarity based on Jaccard similarity coefficient for the seven tomato cultivars tested. The dendrogram produced by the unweighted pair group mean arithmetic method (UPGMA) $(\mathrm{r}=0.81537)$

\section{Discussion}

This study provides a preliminary estimation of the genetic diversity among the Greek landraces and commercial varieties which are currently used in the Greek tomato cultivation areas.

The results support the conclusion that with respect to individual characteristics such as exterior appearance, taste, smell and fruit size, the landraces Homiricon and Lotos are characterized by high value, which is comparable to those of superior commercial varieties. In addition, the combination of yield and quality characteristics based on fruit weight and content of vitamin $\mathrm{C}$, acidity, $\mathrm{pH}$, soluble materials and organoleptic parameters, led to the conclusion that the varieties Homiricon and Lotos can be competitive with the commercial varieties Belladona and Macedonia. Such findings highlight their suitability for their direct use as commercial varieties and/or their potential employment as parents in crosses for hybrid production. Towards this direction, the characterization and the establishment of property rights for these genotypes can be readily done through UPOV indicators such as "green colour of shoulders", shape of fruit, as well as ovaries space, provided that there is a precise recording of traits which would allow for an efficient separation of the studied cultivars.

In terms of overall performance, certain traditional varieties, as Homiricon, were characterized as satisfactory and were superior to cultivated varieties, as Belladona. This fact further strengthens their probable value for commercial cultivation as well as its exploitation for hybrid production, if these traits are combined with other desirable characteristics. It is worth noting however, that parameters of sensory tests must be carefully interpreted, given that estimation errors, derived from the relative CV values, were high for some of the characteristics examined.

Although, RAPD molecular marker analysis consist a routinely used methodology for the purposes of assessing genetic similarity among diverse genetic material, in our case the deduced RAPD profiles showed a reduced reproducibility. Such phenomenon was previously reported for this marker type and may be attributed to an inefficient annealing of primers, to differences in amplification efficiencies as well as to the low annealing temperature used (Mohan et al., 1997). Nevertheless, the primers OPC8 and OPC11 proved the most powerful in distinguishing the examined tomato varieties. In terms of genetic heterogeneity, the analysis revealed relatively high genetic similarity for the cultivars under study. As previously reported this might well be attributed to the general low genetic variation in tomato as well as to low genome coverage, resulting in failure to detect the 
existing polymorphisms (Alvarez et al., 2001). Such low polymorphism level however, has been previously reported using both RAPD molecular markers (Williams \& Clair, 1993; Villand et al., 1998; Echeverrigaray, 2006) or other marker types such as AFLPs (Park et al., 2004), SSRs (Bredemeijer et al., 1998; Carelli et al., 2006) or ISSRs (Terzopoulos \& Bebeli, 2008). The detailed characterization of pre-breeding or breeding materials is of paramount importance both for germplasm collections and breeders in order to enable a more efficient exploitation of the existing gene pool in plant breeding programs. To this purpose, the study and conservation of genetic diversity is increasingly gaining interest, given the progressive narrowing of the crop's genetic base. Such discrimination of genetic diversity however requires the sampling of various types of genetic material, so as to ensure the inclusion of low frequency alleles (Carelli et al., 2006). At the same time, the employment of agronomic, physicochemical and sensory traits in combination with molecular data is anticipated to provide a more reliable estimation of the useful genetic variability. The latter, could be exploited for the development of improved tomato cultivars as well as the identification and registration of landraces with superior performance.

\section{Conclusions}

An integrated description of traditional tomato cultivars includes the record of morphological and qualitative (physicochemical and organoleptic) parameters. Further exploitation of DNA fingerprinting supports the characterization and differentiation of tomato cultivars when cultivated under different culture conditions and practices. Also, a combined multivariate analysis based on morphological and sensory properties is capable to separate similarly the genetic relationships among tomato cultivars when cultivated under organic culture conditions. All these information are useful for the protection of this traditional genetic material and for the direct exploitation or indirect participation into tomato breeding programs aiming at enhancing nutrient value and organoleptic properties.

\section{References}

Alvarez, A. E., Van De Wiel, C. C. M., Vosman, B., \& Smulders, M. J. M. (2001). Use of microsatellites to evaluate genetic diversity and species relationships in the genus Lycopersicon. Theor. Appl. Genet., 103, 1283-1292. http://dx.doi.org/10.1007/s001220100662

Atherton, J. G., \& Rudlich, J. (1986). The tomato crop: a scientific basis for improvement (pp. 85-97 \& pp. 546-579). Chapman and Hall ltd.

Aust, O., Ale-Agha, N., Zhang, L., Wollersen, H., Sies, H., \& Stahl, W. (2003). Lycopene oxidation product enhances gap junctional communication. Food Chem. Toxicol., 41, 1399-1407. http://dx.doi.org/10.1016/S0278-6915(03)00148-0

Benter, T., Papadopoulos, S., Pape, M., Mannas, M., \& Poliwoda, H. (1995). Optimization and reproducibility of random amplified polymorphic DNA in human. Anal Biochem., 230(1), 92-100. http://dx.doi.org/10.1006/abio.1995.1442

Bredemeijer, G. M. M., Arens, P., Wouters, D., Visser, D., \& Vosman, B. (1998). The use of semi-automated fluorescent microsatellite analysis for tomato cultivars identification. Theor. Appl. Genet., 97, 584-590. http://dx.doi.org/10.1007/s001220050934

Carelli, B. P., Gerald, L. T. S., Grazziotin, F. G., \& Echeverrigaray, S. (2006). Genetic diversity among Brazilian cultivars and landraces of tomato Lycopersicon esculentum Mill. revealed by RAPD markers. Genet. Resour. Crop Evol., 53, 395-400. http://dx.doi.org/10.1007/s10722-004-0578-9

Chen, F. Q., Foolad, M. R., Hyman, J., St. Clair, D. A., \& Beelaman, R. B. (1999). Mapping of QTLs for lycopene and other fruit traits in a Lycopersicon esculentum $x$ L. pimpinellifolium cross and comparison of QTLs across tomato species. Molecular Breeding, 5, 283-299. http://dx.doi.org/10.1023/A:1009656910457

Clinton, S. K., Emenhise, C., Schwartz, S. J., Bostwick, D. G., Williams, A. W., Moore, B. J., \& Erdman, J. W. (1996). Cis-trans lycopene isomers, carotenoids, and retinol in the human prostate. Cancer Epidemiol. Biomarkers Prev., 5, 823-833.

Collard, B. C. Y., \& Mackill, D. J. (2008). Marker-assisted selection: an approach for precision plant breeding in the twenty-first century. Philosophical Transactions of the Royal Society B., 363(1491), 557-572. http://dx.doi.org/10.1098/rstb.2007.2170

Di Mascio, P., Kaiser, S., \& Sies, H. (1989). Lycopene as the most efficient biological carotenoid singlet oxygen quencher. Arch. Biochem. Biophys., 274, 532-538. http://dx.doi.org/10.1016/0003-9861(89)90467-0

Dorais, M., Ehret, D. L., \& Papadopoulos, A. P. (2008). Tomato (Solanum lycopersicum) health components: from the seed to the consumer. Phytochem. Rev., 7, 231-250. http://dx.doi.org/10.1007/s11101-007-9085-x 
Doyle, J. J., \& Doyle, J. L. (1990). Isolation of plant DNA from fresh tissue. Focus, 12, 13-15.

Echeverrigaray, S. (2006). Genetic diversity among Brazilian cultivars and landraces of tomato Lycopersicon esculentum Mill. revealed by RAPD markers. Genet. Resour. Crop Evol., 53, 395-400. http://dx.doi.org/10.1007/s10722-004-0578-9

Fernie, A. R., Tadmor, Y., \& Zamir, D. (2006). Natural genetic variation for improving crop quality. Current Opinion in Plant Biology., 9, 196-202. http://dx.doi.org/10.1016/j.pbi.2006.01.010

Foolad, M. R., \& Panthee, D. R. (2012). Marker-assisted selection in tomato breeding. Critical Reviews in Plant Sciences, 31, 93-123. http://dx.doi.org/10.1080/07352689.2011.616057

Georgelis, N., \& Scott, J. W., \& Baldwin, E. A. (2004). Relationship of tomato fruit sugar concentration with physical and chemical traits and linkage of RAPD markers. J. Amer. Soc. Hort. Sci., 129(6), 839-845.

Gerster, H. (1997). The potential role of lycopene for human health. J. Am. Coll. Nutr., 16, 109-126.

Mavromatis, A. G., Athanasouli, V., Voudouri, A., Nakas, C., Korkovelos, A., Khah, E. A., ... Goulas, C. K. (2008). Pure Line Selection for breeding traditional tomato landraces according to agronomic and quality traits. In Proceedings of Hellenic Committee in Genetics \& Plant Breeding. Eds Hellenic Plant Breeding Society (Naousa, Greece).

Mavromatis, A. G., Arvanitoyannis, I. S., Korkovelos, A. E., Giakountis, A., Chatzitheodorou, V. A., \& Goulas, C. K. (2010). Genetic diversity among common bean (Phaseolus vulgaris spp) Greek landraces and commercial cultivars: nutritional components, Rapd and morphological markers. Spanish Journal of Agricultural Research, 8(4), 986-994

Madhavi, D. L., \& Salunkhe, D. K. (1998). Production, composition, storage and processing. In D. K. Salunkhe, \& S. S. Kadam (Eds.), Tomato, Handbook of Vegetable Science and Technology (pp. 171-201). New York: Marcel Dekker.

Nei, M., \& Li, W. H. (1979). Mathematical model for studying genetic variation in terms of restriction endonucleases. Proc. Nalt. Acad. Sci., 76, 5269-5273. http://dx.doi.org/10.1073/pnas.76.10.5269

Razdan, M. K., \& Mattoo, A. K. (2008). Genetic improvement of solanaceous crops. Journal of Plant Physiology, 165, 1317-1318.

Rick, C. M. (1978). The Tomato. Scientific American, 239(2), 76-87.

Rolf, F. J. (1983). Numerical taxonomy and multivariate analysis system version. In Applied Biostatics, New York.

Sarris, F. P., Trantas, M., \& Fanourakis, N. (2005). Comparison of genetic polymorphism assessed by RAPD analysis and description of morphological characters for two Greek cucumber varieties. In « $3^{\text {rd }}$ International Cucurbit Symposium» in Townsville, Australia, 11-17 September 2005.

Sneath, P. H. A., \& Sokal, R. R. (1973). Numerical taxonomy. San Francisco.

Stam, J. G., Chavalitshewinkoon, P., De Vries, E., Franssen, F. F., Van Der Vliet, P. C., \& Overdulve, J. P. (1993). Purification and characterization of DNA polymerases from Plasmodium falciparum. Mol Biochem Parasitol., 61(2), 243-53. http://dx.doi.org/10.1016/0166-6851(93) 90070-E

Tanksley, S. D. (1987). Organization of the nuclear genome in tomato and related diploid species. Am Nat., 130, 46-56.

Terzopoulos, P. J., \& Bebeli, P. J. (2008). DNA and morphological diversity of selected Greek tomato (Solanum $\begin{array}{llllll}\text { lycopersicum } & \text { L.) } & \text { landraces. } & \text { Scientia } & \text { Horticulturae, } & \text { 116, }\end{array}$ http://dx.doi.org/10.1016/j.scienta.2008.02.010

Villand, J., Skroch, P. W., Lai, T., Hanson, P., Kuo, C. G., \& Nienhuis, J. (1998). Genetic variation among tomato accessions from primary and secondary centers of diversity. Crop Sci., 38, 1339-1347.

Williams, C. E., \& St. Clair, D. A. (1993). Phenetic relationships and levels of variability detected by restriction fragment length polymorphism and random amplified polymorphic DNA analysis of cultivated and wild accessions of Lycopersicon esculentum. Genome, 36, 619-630. http://dx.doi.org/10.1139/g93-083

Zamir, D., \& Tanksley, S. D. (1988). Tomato genome is comprised largely of fast-evolving low copy-number sequences. Mol. \& Gen. Genet., 213, 254-261. http://dx.doi.org/10.1007/BF00339589 